Brit. J. vener. Dis. (1961), 37, 239.

\title{
MEDICAL SOCIETY FOR THE STUDY OF VENEREAL DISEASES MEETING IN PARIS, 1961
}

The Medical Society for the Study of Venereal Diseases, the first thirty years of whose history we have recorded in a recent number, ${ }^{*}$ held its first overseas meeting at the Institut Fournier, Paris, in May, 1961. The programme, reproduced below, bears witness to the planning and organization which ensured its success and was highly appreciated by the members and their guests who gathered together in Paris. They will wish to join us in warmly thanking the many people and, in particular, Dr. and Mme Pierre Durel, and Dr. and Mrs Claude Nicol, who contributed so much to making the occasion memorable.

The scientific sessions, contributions to which are published in this issue of the Journal, were happily blended with social and cultural activities. These latter made a major contribution to the value and enjoyment of the meeting by providing favourable opportunities for making and renewing friendships and for informal discussion of medical problems of common interest. They catalyse the exchange of ideas and stimulate further thought so that the beneficial effects of the meeting continue long after those attending have gone their separate ways.

The choice of Paris as the host city was a particularly happy one. If, as we hope, the Society again ventures to meet overseas, our hosts and the officials of the Society responsible for organizing these meetings, will find it hard to emulate the standards achieved this year in Paris.

${ }^{*}$ Harrison, L. W. (1961). Brit. J. vener. Dis., 37, 2.

\section{PROGRAMME OF PARIS MEETING, 1961}

\author{
Friday $\quad 9.30$ a.m. Scientific Meeting (1st session) at \\ May 12 \\ 12.30 p.m. Reception in Library, Institut \\ Fournier. \\ 1.00 p.m. Lunch at Hôtel Barrault. \\ 2.30 p.m. Scientific Meeting (2nd session) at \\ Institut Fournier. \\ 7.00 p.m. Reception given by Dr. and Mme \\ Durel at la Maison des Poly- \\ techniciens. \\ Ladies' Programme (during Scientific Meetings) \\ Morning Visit to Musée du Louvre (with \\ English guide). \\ Lunch at Magasins du Louvre. \\ Afternoon 2.0 p.m.- Visit to the House of \\ Christian Dior.
}

Saturday (By courtesy of Messrs. Specia Ltd.)

May 1310.30 a.m. Trip by L.e Borde Fretigny on the Seine to Melun.

Lunch on the boat.

Return by bus via Flins to Paris 6.30 p.m.

Sunday (By courtesy of Messrs. May and Baker Ltd.) May 14 Morning Trip by bus round old Paris.

12.00 noon M.S.S.V.D. Luncheon at Hôtel Lutetia,

Afternoon Trip by bus to the Palais de Versailles, returning to Le Bourget Airport. 